Published in "Chemical Geology 244(3-4): 679-690, 2007"

which should be cited to refer to this work.

\title{
In situ measurements of calcium isotopes by ion microprobe in carbonates and application to foraminifera
}

\author{
Claire Rollion-Bard $^{\mathrm{a}, *}$, Nathalie Vigier ${ }^{\mathrm{a}}$, Silvia Spezzaferri ${ }^{\mathrm{b}}$ \\ ${ }^{a}$ Centre de Recherches Pétrographiques et Géochimiques, BP 20, 15 rue Notre Dame des Pauvres, 54501 Vandoeuvre-lès-Nancy Cédex, France \\ ${ }^{\mathrm{b}}$ University of Fribourg, Department of Geosciences, Geology and Paleontology, Ch du Musée 6, CH 1700 Fribourg, Switzerland
}

\begin{abstract}
An analytical procedure has been developed for the in situ measurement of calcium isotope composition of carbonates with a spatial resolution of 15-20 $\mu \mathrm{m}$ on a Caméca IMS 1270 ion microprobe. By using two Faraday cup detectors, the ${ }^{40} \mathrm{Ca}$ and ${ }^{44} \mathrm{Ca}$ can be measured simultaneously, improving the internal reproducibility. Instrumental mass fractionation (IMF) of calcium isotopes was observed to be independent of primary ion beam intensity and of the $\mathrm{Mg}$ content of the carbonate, but can depend on vacuum conditions. Three calcite reference materials were used in this study (ENS 0, MEX and BRET 105E) and their $\delta^{44} \mathrm{Ca}$ values relative to NIST915a were reproducible within a typical $1 \sigma$ standard deviation of $\approx 0.15 \%$.

This analytical procedure was applied to planktonic foraminifera, Globorotalia inflata, dated at 2.8 Ma from Shatsky Rise (ODP leg 198). The range of measured $\delta^{44} \mathrm{Ca}$ within a single test is $1.7 \%$. This intratest variation can be attributed to several processes such as temperature variation, ontogenic effects or differences between primary and secondary calcite (i.e. calcite precipitated by different biomineralization processes).

Despite this intratest variation, the averages $\delta^{44} \mathrm{Ca}$ for each foraminifer are similar and are in agreement with published $\delta^{44} \mathrm{Ca}$ values measured for this age. This study shows that in situ $\delta^{44} \mathrm{Ca}$ measurements in tests of foraminifera are an appropriate tool for investigating biomineralization processes.
\end{abstract}

Keywords: Calcium isotopes; Ion microprobe; Calcite; Foraminifera

\section{Introduction}

Calcium plays a major role in many geological and biological processes. $\mathrm{Ca}$ has five naturally stable isotopes with abundances of: ${ }^{40} \mathrm{Ca}(96.941 \%),{ }^{42} \mathrm{Ca}$ $(0.647 \%),{ }^{43} \mathrm{Ca}(0.135 \%),{ }^{44} \mathrm{Ca}(2.086 \%)$ and ${ }^{46} \mathrm{Ca}$ $(0.004 \%)$, and one more isotope, with such a long half-

\footnotetext{
* Corresponding author. Tel.: +33 3835942 36; fax: +33 3511798 . E-mail address: rollion@crpg.cnrs-nancy.fr (C. Rollion-Bard).
}

life $\left(6 \times 10^{18}\right.$ years $)$ that it can be considered as stable, ${ }^{48} \mathrm{Ca}(0.187 \%)$. Natural variations of $\mathrm{Ca}$ isotope ratios may be introduced by beta-decay of the potassium isotope ${ }^{40} \mathrm{~K}$ (half-life: $1.277 \times 10^{9}$ years) increasing the relative abundance of ${ }^{40} \mathrm{Ca}$ (Marshall and DePaolo, 1982; Nägler and Villa, 2000). In carbonates, K abundance can be considered as negligible, preventing any in situ growth of ${ }^{40} \mathrm{Ca}$. Ca isotopes can also fractionate during physico-chemical processes such as calcite precipitation with a fractionation $\Delta^{44 / 40} \mathrm{Ca}$ 
between 0 and $-1.8 \%$ depending on the precipitation rate (Lemarchand et al., 2004; Marriott et al., 2004).

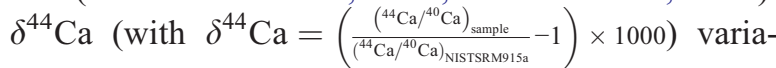
tions in biogenic carbonates can be interpreted in terms of geological, kinetic and/or biological processes. As a result of the different kinds of behaviour of $\delta^{44} \mathrm{Ca}$ in biogenic carbonates, various authors have used $\mathrm{Ca}$ isotope ratios of biomaterials as tracers of (i) biomineralization by either using soft tissue and dietary $\delta^{44} \mathrm{Ca}$ as an indicator of the calcium balance in living organisms (Skulan and DePaolo, 1999) or by using the fractionation of calcium isotopes during metabolic processes (Clementz et al., 2003), (ii) the global calcium cycle (De La Rocha and DePaolo, 2000; Fantle and DePaolo, 2005; Heuser et al., 2005; Farkas et al., 2007), and (iii) marine paleotemperatures ( $\mathrm{Zhu}$ and MacDougall, 1998; Nägler et al., 2000; Gussone et al., 2004; Immenhauser et al., 2005; Hippler et al., 2006). The importance of $\mathrm{Ca}$ for foraminiferal biology suggests that the $\mathrm{Ca}$ isotope fractionation may be biologically mediated and hence may also contain information about the mechanisms of calcification in foraminifera and in other biological carbonates such as corals (Böhm et al., 2006) and coccolithophores (Gussone et al., 2006; Langer et al., 2007). In addition to changes in temperature and biological processes, variation in ancient foraminifera $\delta^{44} \mathrm{Ca}$ may reflect changes in oceanic $\delta^{44} \mathrm{Ca}$ values and observed changes have been attributed to differences in past weathering inputs (De La Rocha and DePaolo, 2000; Fantle and DePaolo, 2005). Thus, the $\delta^{44} \mathrm{Ca}$ values in foraminifera could provide insight on paleotemperatures, biomineralization processes and also changes in weathering inputs, linked to the carbon cycle. Until now, Ca isotopes ratios in carbonates have been measured using TIMS and MC-ICPMS techniques on bulk samples. With the use of an ion probe, it should be possible to measure several spots in one single test and thus to explore possible intratest variability. This new aspect should allow the link between biomioneralization mechanism and $\mathrm{Ca}$ isotope fractionation to be studied from a different angle.

In many studies, the ion microprobe has proved to be an essential tool as a result of its ability to perform in situ measurements of isotopic/elemental compositions. Pioneering ion microprobe development measured $\mathrm{Ca}$ isotopes with an analytical precision around $\pm 5.4 \%$ o $\left(2 \sigma_{\mathrm{n}}\right)$ for $\delta^{48 / 40} \mathrm{Ca}$ in $\mathrm{CM}$ and $\mathrm{CV}$ meteorites (Sahijpal et al., 2000), and around $\pm 3 \%$ o $(1 \sigma)$ for $\delta^{42 / 40} \mathrm{Ca}, \delta^{43 / 40} \mathrm{Ca}$ and $\delta^{48 / 40} \mathrm{Ca}$ in $\mathrm{Ca}-\mathrm{Al}$-rich inclusions of meteorites (Weber et al., 1995). For environmental applications, better precision is needed, and therefore we have systematically tested the factors that determine $\delta^{44} \mathrm{Ca}$ precision by ion microprobe in carbonates.

Instrumental mass fractionation (IMF) during calcium isotope measurement, which causes the measured isotope ratios to be shifted towards values usually depleted in the heavy isotope compared to the true abundances (Shimizu and Hart, 1982), is defined as:

$\alpha_{\text {inst }}=\frac{\left({ }^{44} \mathrm{Ca} /{ }^{40} \mathrm{Ca}\right)_{\text {meas }}}{\left({ }^{44} \mathrm{Ca} /{ }^{40} \mathrm{Ca}\right)_{\text {true }}}$,

where $\left({ }^{44} \mathrm{Ca} /{ }^{40} \mathrm{Ca}\right)_{\text {meas }}$ is the calcium isotope ratio measured by ion microprobe with no correction for instrumental fractionation and $\left({ }^{44} \mathrm{Ca} /{ }^{40} \mathrm{Ca}\right)_{\text {true }}$ is the calcium isotope ratio measured by a conventional method. The IMF can also be reported in permil units $\left(\Delta_{\text {inst }}\right)$, calculated using:

$\Delta_{\text {inst }}=1000 \times \ln \left(\alpha_{\text {inst }}\right)$.

The IMF variability and its dependence on instrumental conditions are known to be the main limitation for the precision and accuracy of ion microprobe analyses (Shimizu and Hart, 1982). Values of $\alpha_{\text {inst }}$ are usually determined on reference materials of known isotopic composition, which are analysed under the same conditions as the samples. The most commonly applied correction scheme consists of determination of the IMF by analysing reference materials of chemical and physical properties identical to the sample. This standard procedure has successfully been applied to $\delta^{11} \mathrm{~B}, \delta^{13} \mathrm{C}, \delta^{18} \mathrm{O}$ and $\delta^{7} \mathrm{Li}$ measurements in pure matrices like calcite or aragonite (e.g. Rollion-Bard et al., 2003; Vigier et al., 2007).

This study tests the main instrumental conditions that are likely to vary from analysis to analysis and their influence on the IMF. This development is applied to $\delta^{44} \mathrm{Ca}$ measurements in calcites and, we present, for the first time, in situ $\delta^{44} \mathrm{Ca}$ measurements, with an average precision of $\pm 0.15 \%$ o $(1 \sigma)$. This analytical precision allows us to quantify the intra-shell variability of $\delta^{44} \mathrm{Ca}$ in tests of planktonic foraminifera (Globorotalia inflata).

\section{Reference materials and samples}

Three calcite reference materials were used: A calcite experimentally precipitated from NIST SRM 915a powder and two natural calcites, MEX and BRET 105E. The method of precipitation is as follows. A calcite standard (ENS 0) was synthesized hydrothermally (under high temperature and pressure). A powder of NIST SRM 915a 
Table 1

Ion microprobe Caméca IMS 1270 settings

\begin{tabular}{ll}
\hline Primary source ions & ${ }^{16} \mathrm{O}^{-}$ \\
Primary beam intensity & $10-15 \mathrm{nA}$ \\
Field aperture & $5000 \mu \mathrm{m}$ \\
Entrance slit & $80 \mu \mathrm{m}$ \\
Exit slit & Multicollection no. $1: 500 \mu \mathrm{m}$ \\
Mass resolution power (MRP) & $\approx 5000$ \\
\hline
\end{tabular}

calcite was enclosed, together with $\mathrm{LiOH}$ and de-ionized water, in a gold capsule, which was welded shut. The sample was run at $550{ }^{\circ} \mathrm{C}$ and $150 \mathrm{MPa}$ for 1 week in an externally heated pressure vessel at the ENS (Ecole Nationale Supérieure, Paris). The run product is composed of sub-millimetre calcite grains (as confirmed by Raman micro-spectrometry). The calcite produced was rinsed with de-ionized water before sample preparation and analyses. $\delta^{44} \mathrm{Ca}$ values determined by TIMS, relative to NIST SRM $915 \mathrm{a}$, for these reference materials are $0.94 \pm 0.1 \% 0$ (MEX) and $0.74 \pm 0.11 \%$ (BRET 105E) (A. Eisenhauer, pers. com.). By definition, the $\delta^{44}$ Ca of NIST SRM 915a is $0 \%$.

The studied specimens of $G$. inflata (planktonic foraminifera) were picked from sediments retrieved during ODP leg 198 (Shatsky Rise) at hole 1209A $\left(32^{\circ} 39 \mathrm{~N}, 158^{\circ} 30 \mathrm{E}\right)$. Site 1209 is located at $2387-\mathrm{m}$ water depth (middle bathyal) close to the most elevated, central part of the Southern High of Shatsky Rise. ODP Hole 1209A was drilled to $259.6 \mathrm{~m}$ below sea floor (mbsf) into a Paleogene section. Studied G. inflata are from 1209A4H-CC (Zone N21). They are dated at 2.8 Ma.

Contamination from clay minerals, iron and manganese oxide coatings, barite crystals, calcareous nanofossils, and organic material is often a major problem in trace element and isotopic analyses performed using a batch of bulk tests. Most contamination is acquired after the death of the organism onto the outer surface of the tests or accumulated in pores. The pre-cleaning techniques that are classically used aim therefore at eliminating the contaminant phases located on the exterior of the test and within chamber cavities (e.g. Martin and Lea, 2002; Pena et al., 2005). Using the 1270 ion microprobe, cleaning procedures are not required because measurements can be done on small spots located in the centre of calcite walls. Before analyses, reference materials and samples were embedded in epoxy sections, polished using a diamond paste down to $1 \mu \mathrm{m}$ and then coated with gold.

\section{Ion microprobe measurements}

The ion microprobe calcium isotope compositions reported in this study were determined using the Caméca
IMS 1270 ion microprobe at CRPG-CNRS, Nancy, France.

\subsection{Basic settings}

A liquid nitrogen cold-trap was used to remove water from the residual gases and to lower the gas pressure in the specimen chamber. Samples were sputtered with a primary beam of ${ }^{16} \mathrm{O}^{-}$ions of $10-$ 15-nA intensity. The primary beam was focused through the primary diaphragm to produce an ellipsoid, flat-bottomed crater of around $10-15-\mu \mathrm{m}$ length and $5-10-\mu \mathrm{m}$ width. Secondary positive $\mathrm{Ca}$ ions were accelerated at $10 \mathrm{kV}$ and transfer optics of $150 \mu \mathrm{m}$ and field aperture of $5000 \mu \mathrm{m}$ were used. The analyses were performed without energy filtering and the energy window was fully opened. The circular focusing mode was used. The mass spectrometer entrance and exit slits were closed to achieve a mass resolution $(M / \Delta M)$ of $\approx 5000$. Secondary ${ }^{40} \mathrm{Ca}^{+}$and ${ }^{44} \mathrm{Ca}^{+}$ions were simultaneously measured in multicollection mode using two off-axis faraday cups $\left(\mathrm{L}^{\prime} 2\right.$ and H1). The relative gains of faraday cups and amplifiers were calibrated at the beginning of the analytical session using the Caméca built-in amplifier calibration routine (De Chambost, 1997). Count rates were typically in the $8 \times 10^{6}-1 \times 10^{7}$-cps (counts per second) range for the ${ }^{44} \mathrm{Ca}^{+}$on calcite reference materials and on foraminifera. All these analytical settings are summarized in Table 1. One analysis consists of 25 cycles of $3 \mathrm{~s}$ each.

\subsection{Interferences}

For the measurement of $\delta^{44} \mathrm{Ca}$, a MRP (mass resolution power) of at least 4500 is required to resolve most common isobaric interferences, as shown in Table 2. We performed the measurement in multicollection mode with a MRP around $\approx 5000$ (Fig. 1). The peaks of ${ }^{40} \mathrm{Ca}^{+}$

Table 2

Interferences and mass resolutions needed to resolve them from ${ }^{40} \mathrm{Ca}^{+}$ and ${ }^{44} \mathrm{Ca}^{+}$peaks

\begin{tabular}{llll}
\hline Elements & MRP & Elements & MRP \\
\cline { 3 - 4 } Mass 40 & & Mass 44 & \\
\hline${ }^{40} \mathrm{Ca}$ & - & ${ }^{88} \mathrm{Sr}^{2+}$ & -18000 \\
${ }^{40} \mathrm{~K}$ & +28000 & ${ }^{44} \mathrm{Ca}$ & - \\
${ }^{39} \mathrm{KH}$ & +4470 & ${ }^{43} \mathrm{CaH}$ & +3960 \\
${ }^{24} \mathrm{Mg}^{16} \mathrm{O}$ & +2301 & ${ }^{26} \mathrm{Mg}^{18} \mathrm{O}$ & +1674 \\
& & ${ }^{12} \mathrm{C}^{16} \mathrm{O}_{2}$ & +1280 \\
\hline
\end{tabular}

MRP: Mass resolution power needed to separate the peaks. 


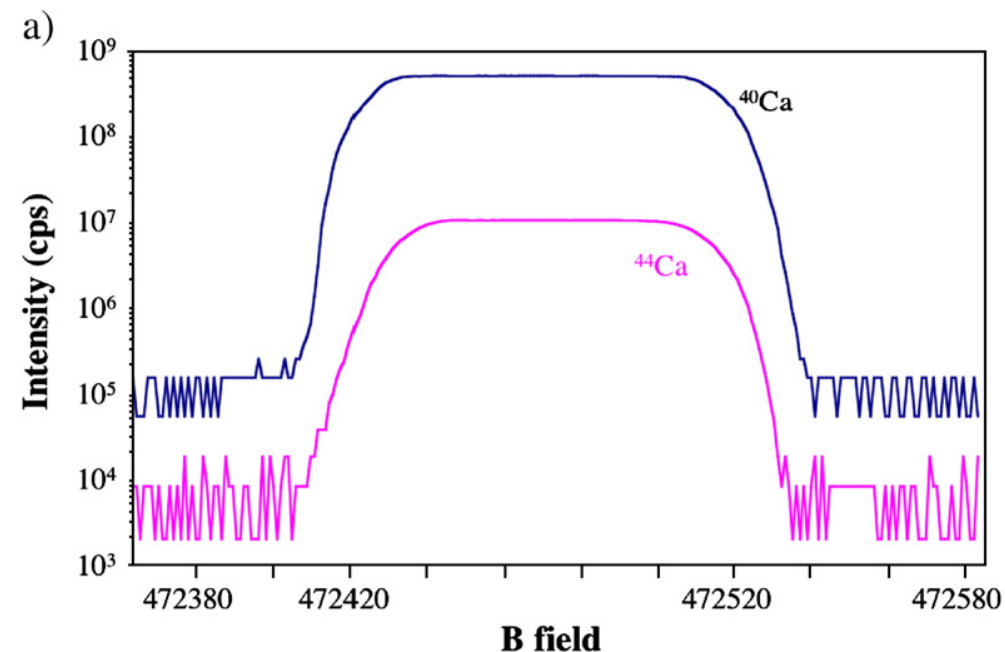

b)

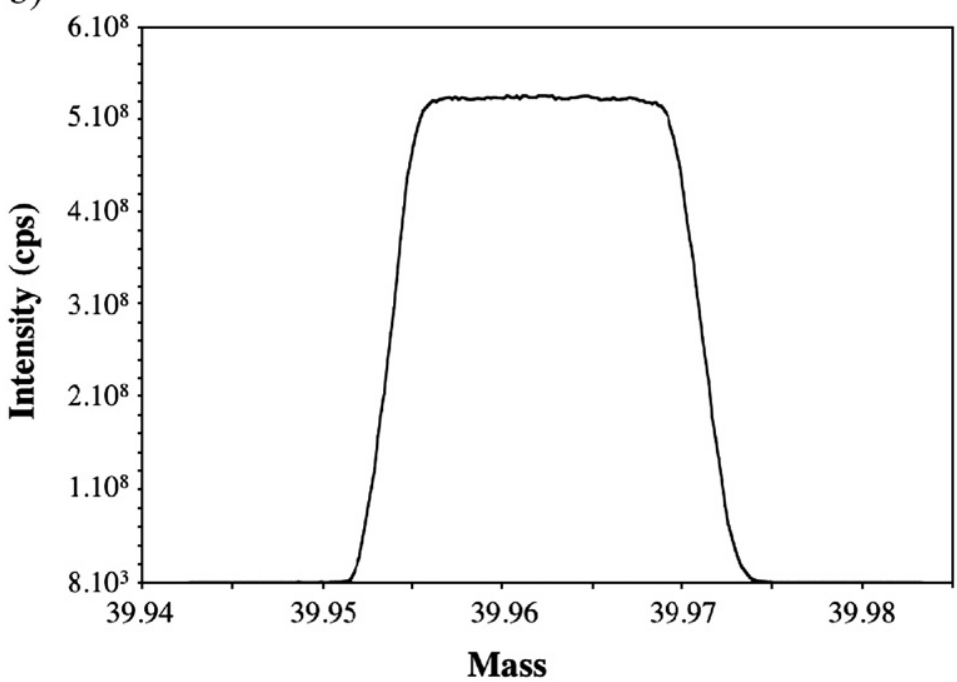

Fig. 1. High resolution mass spectra showing in a) the ${ }^{40} \mathrm{Ca}^{+}$and ${ }^{44} \mathrm{Ca}^{+}$peaks in multicollection and on a log scale, and in b) at mass 40 , the ${ }^{40} \mathrm{Ca}^{+}$peak on a linear scale.

and ${ }^{44} \mathrm{Ca}^{+}$have a flatness $\mathrm{d} I / I$ ( $I=$ intensity) better than $0.1 \%$ for a range of $20 \mathrm{ppm}$. However, two interferences cannot be resolved at this MRP: the ${ }^{40} \mathrm{~K}^{+}$peak on ${ }^{40} \mathrm{Ca}^{+}$ and the ${ }^{88} \mathrm{Sr}^{2+}$ peak on the ${ }^{44} \mathrm{Ca}^{+}$peak (needing +28000 and -18000 of MRP, respectively). To check for the possible interference of ${ }^{40} \mathrm{~K}^{+}$on ${ }^{40} \mathrm{Ca}^{+}$, we monitored mass $41\left({ }^{41} \mathrm{~K} /{ }^{40} \mathrm{~K} \approx 576\right)$ after each in situ analysis. The isobaric interference on mass 40 was found to be negligible in carbonates. To check if interference by ${ }^{88} \mathrm{Sr}^{2+}$ significantly effects our measurements, we also systematically measured mass $43.5\left({ }^{87} \mathrm{Sr}^{2+}\right)$. The counts were no more than 20-30 cps, representing around 230$350 \mathrm{cps}$ of ${ }^{88} \mathrm{Sr}^{2+}\left({ }^{87} \mathrm{Sr}\right.$ has an abundance of $7.001 \%$ and ${ }^{88} \mathrm{Sr} 82.581 \%$ ), negligible compared to the counts of ${ }^{44} \mathrm{Ca}^{+}\left(8-10 \times 10^{6} \mathrm{cps}\right)$.

\subsection{Data notation and correction}

The standard normally used as a reference material is NIST SRM 915a (Coplen et al., 2002; Carignan et al., 2004; Eisenhauer et al., 2004). However, other reference materials are used in the literature such as reagent calcium fluoride $\mathrm{CaF}_{2}$, natural $\mathrm{CaF}_{2}$, a Tridacna shell, seawater or an ultrapure $\mathrm{CaCO}_{3}$ (e.g. Fletcher et al., 1997; Skulan et al., 1997; Zhu and MacDougall, 1998; Nägler et al., 2000; De La Rocha and DePaolo, 2000; Schmitt et al., 2003).

In the present study, calcium isotope ratios are expressed as a delta notation, $\delta^{44} \mathrm{Ca}$, relative to NIST SRM 915a. All carbonate samples analysed by ion microprobe were first standardized with MEX. Then, 

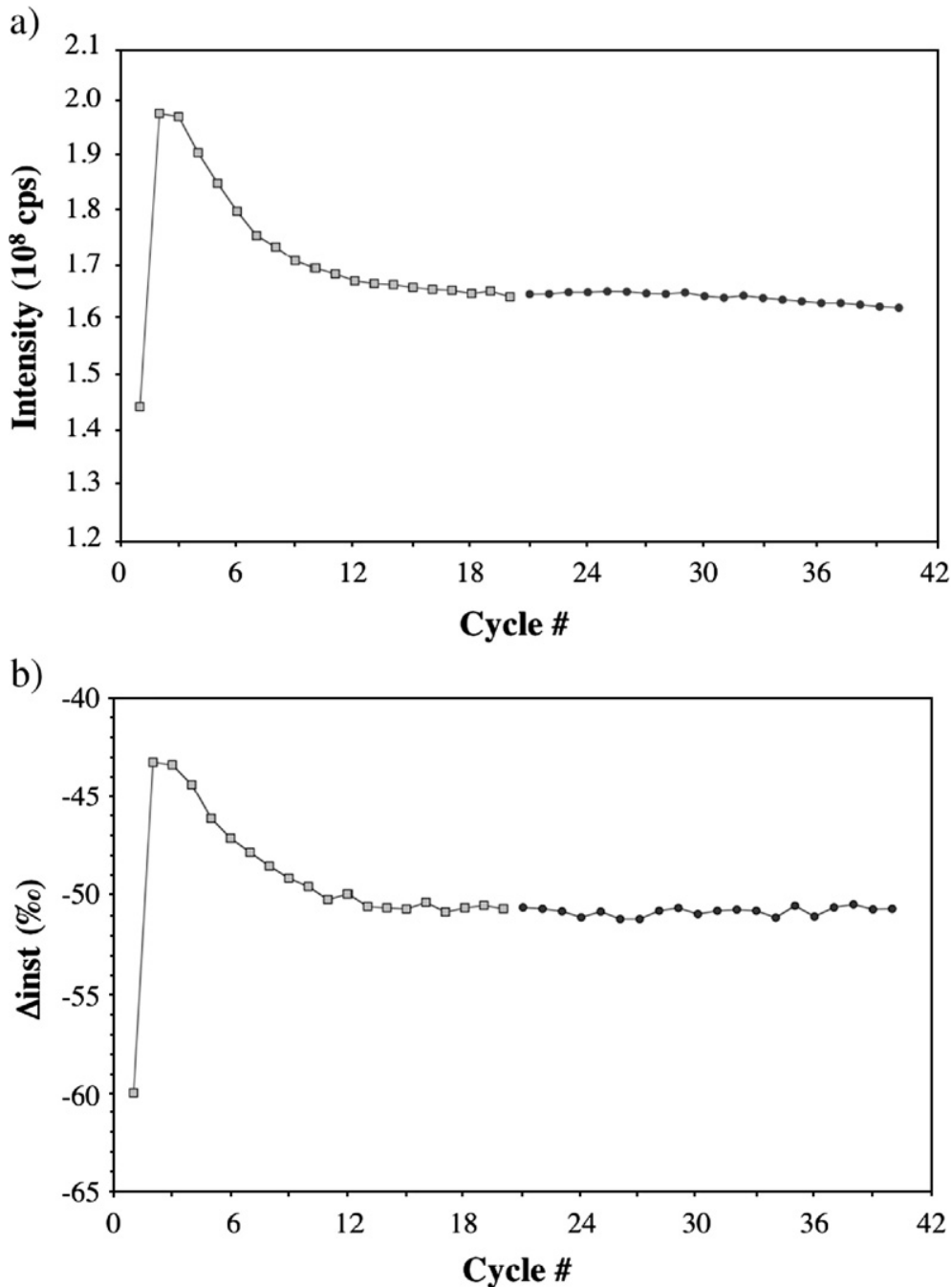

Fig. 2. Intensity of ${ }^{40} \mathrm{Ca}^{+}$(a) and $\Delta_{\text {inst }}$ (b) as a function of pre-sputtering time on MEX standard. Intensity and $\Delta_{\text {inst }}$ increase and reach a plateau after cycle \#12. After this cycle, intensity and $\Delta_{\text {inst }}$ can be considered to be constant. Repeated measurement in the same spot (black circles) indicates no degradation of the ${ }^{40} \mathrm{Ca}^{+}$intensity and of the $\Delta_{\text {inst }}$.

each $\delta^{44} \mathrm{Ca}$ measurement is calculated relative to NIST 915a according to the following relationship:

$$
\begin{aligned}
\delta^{44} \mathrm{Ca}_{(\text {sample,NIST915a })} \\
=\left(\delta^{44} \mathrm{Ca}_{(\text {MEX,NIST915a) }}+1000\right) \\
\times\left[\frac{\left(\frac{{ }^{40} \mathrm{Ca}}{{ }^{44} \mathrm{Ca}}\right)_{(\text {sample,meas })}}{\left(\frac{{ }^{44} \mathrm{Ca}}{{ }^{40} \mathrm{Ca}}\right)_{(\text {MEX,meas })}}\right]-1000
\end{aligned}
$$

$\left({ }^{44} \mathrm{Ca} /{ }^{40} \mathrm{Ca}\right)_{(\text {MeX,meas }}$ being the average of calcium isotope ratios measured in MEX calcite during the same analytical session as the sample measurements. Samples are analysed only if the drift is negligible for
MEX analyses and if the external reproducibility, given by $\delta^{44} \mathrm{Ca}$ data for MEX, is better than $\pm 0.25 \%$ o $(1 \sigma)$.

\subsection{Testing instrumental conditions}

\subsubsection{Pre-sputtering time}

The sputtering time is a parameter likely to influence the sputter-ionization process (Benninghoven et al., 1987; Janssens et al., 2003) due to implantation of primary ions into the sample, and thus the IMF during $\delta^{44} \mathrm{Ca}$ measurements in carbonates. We note a trend in both ${ }^{40} \mathrm{Ca}^{+}$count rates and $\delta^{44} \mathrm{Ca}$ values from cycle to cycle over a period of around $150 \mathrm{~s}$. After this period, no consistent trend is observed, indicating that sputtering equilibrium has been reached (Fig. 2). However, to test 


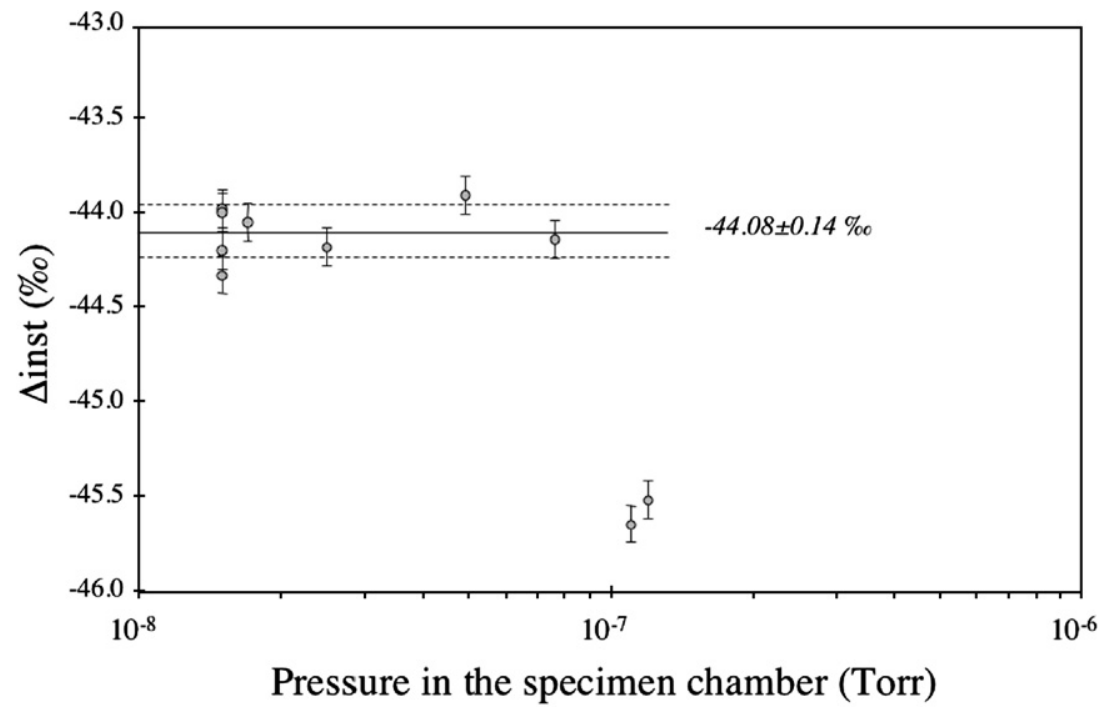

Fig. 3. $\Delta_{\text {inst }}$ measured on the MEX standard during the drop of the pressure in the specimen chamber immediately following introduction of the sample. The magnitude of $\Delta_{\text {inst }}$ decreases by $\approx 2.5 \%$ over the 15 -min pumping time. The solid line indicates the mean $\Delta_{\text {inst }}\left(\bar{\Delta}_{\text {inst }}\right)$ value calculated over measurements performed at pressures below $8 \times 10^{-8}$ Torr. The dashed lines indicate $\bar{\Delta}_{\text {inst }}+1 \sigma$ and $\bar{\Delta}_{\text {inst }}-1 \sigma$ values, where $\sigma$ is the standard deviation obtained for these measurements. Below a pressure of $8 \times 10^{-8}$ Torr, $\Delta_{\text {inst }}$ values can be considered constant within a standard deviation of $\pm 0.14 \%$, which does not exceed the $1 \sigma$ external precision of measurements.

this observation, repeated measurements on the same spots were performed and no degradation of $\Delta_{\text {inst }}$ $\left(\Delta_{\text {inst }}=\delta^{44} \mathrm{Ca}_{(\text {MEX,meas })}-\delta^{44} \mathrm{Ca}_{(\text {MEX,true })}\right)$ values was observed (Fig. 2). Consequently, before all the analyses, we applied a pre-sputtering time between $150 \mathrm{~s}$ and $180 \mathrm{~s}$. A primary beam of $10-15 \mathrm{nA}$ produces a crater of less than $1 \mu \mathrm{m}$ into the calcite.

\subsubsection{Pressure in the specimen chamber}

Vacuum conditions are also likely to influence the sputtering-ionization process (e.g. Sangely et al., 2005). When the vacuum is poor, the probability that secondary ions strike particles present in the specimen chamber is increased and thus disturb the ion yield. When a certain vacuum is reached, this probability becomes very low. In

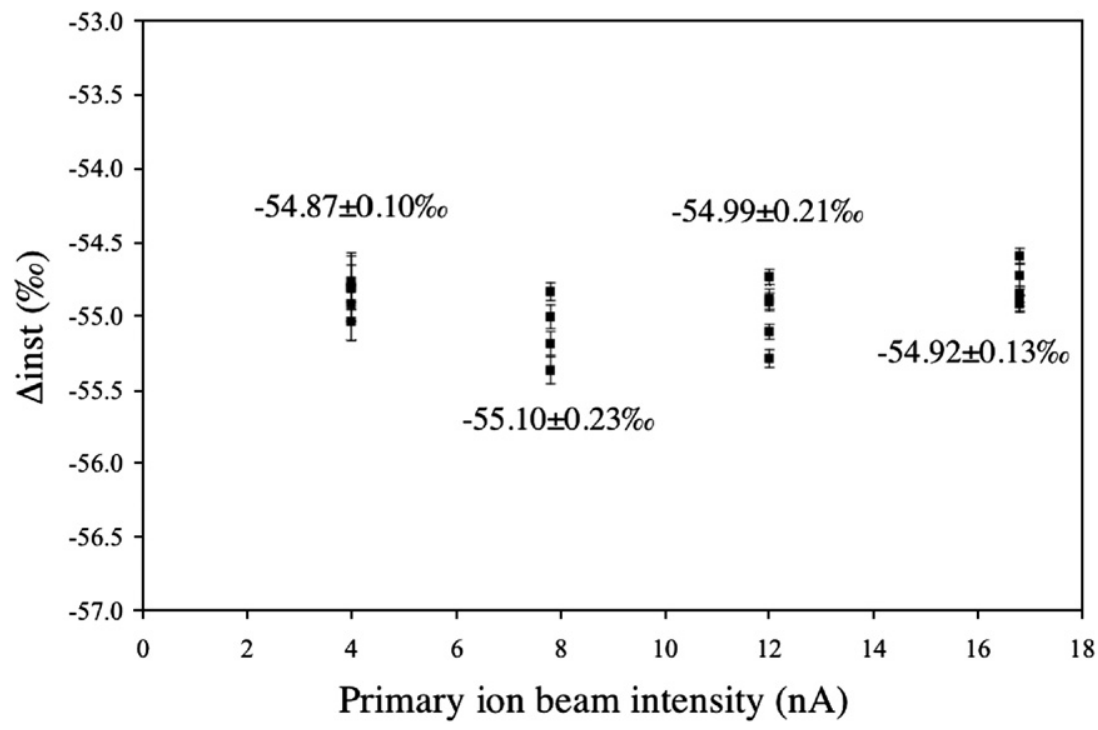

Fig. 4. $\Delta_{\text {inst }}$ values as a function of primary ion beam intensity for BRET $105 \mathrm{E}$ reference material measurements. $\Delta_{\text {inst }}$ was calculated using an arbitrary ${ }^{44} \mathrm{Ca} /{ }^{40} \mathrm{Ca}$ of 0.212116 (no absolute ratio is certified yet for carbonate reference material). We obtained average $2 \sigma_{\mathrm{n}}$ values of $\pm 0.2 \%$ o indicating that $\Delta_{\text {inst }}$ values can be considered as constant over a primary beam intensity ranging from 4 to $16.8 \mathrm{nA}$. 


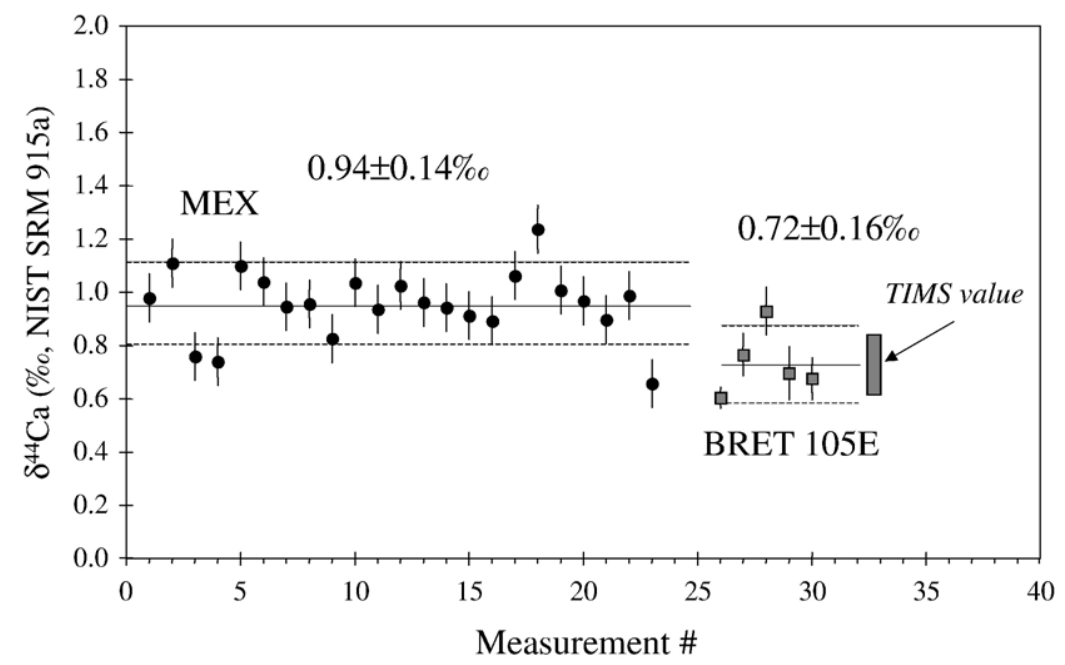

Fig. 5. Point-to-point reproducibility of $\delta^{44} \mathrm{Ca}$ on MEX reference material obtained during a one-day session (black circles). Solid line indicates the mean $\delta^{44} \mathrm{Ca}\left(\bar{\delta}^{44} \mathrm{Ca}\right)$ obtained over the 23-repeated analyses and dashed lines indicate $\bar{\delta}^{44} \mathrm{Ca}+1 \sigma$ and $\bar{\delta}^{44} \mathrm{Ca}-1 \sigma$ values, where $\sigma$ is the standard deviation from the mean $\delta^{44} \mathrm{Ca}$ values. For $n=20-25$, we obtained typical $1 \sigma$ values of $\pm 0.13 \%$ for the standards. Values for BRET $105 \mathrm{E}$ (grey squares) were obtained using the $\Delta_{\text {inst }}$ determined with MEX standard. Within instrumental errors, no difference is observed between $\delta^{44} \mathrm{Ca}$ measured on BRET $105 \mathrm{E}$ by ion microprobe and the value obtained by TIMS (grey rectangle).

this section, we examine whether variations in the specimen chamber pressure affect the IMF. $\Delta_{\text {inst }}$ values were monitored during the 15 -min pumping following the introduction of the sample in the specimen chamber, when the pressure drops from $1.2 \times 10^{-7}$ to $1.5 \times 10^{-8}$ Torr. An increase of $1.4 \%$ was observed over this pressure range (Fig. 3). However, when the pressure reached a threshold of about $8 \times 10^{-8}$ Torr, $\Delta_{\text {inst }}$ can be considered as constant within a $1 \sigma$ standard deviation of $\pm 0.14 \%$, corresponding to the external reproducibility of measurements.

\subsubsection{Primary beam intensity}

In some cases, changes in the intensity of the primary ion beam could not be avoided during the course of an analytical session, due to slight change in pressure in the duoplasmatron source, or to the erosion of the primary diaphragm, for instance. The second lens of the primary column optical system (L2) was used to change the intensity of the primary ion beam. $\delta^{44} \mathrm{Ca}$ measurements were repeated on BRET 105E reference material using primary ion beam intensities ranging from 4 to $16.8 \mathrm{nA}$. The $\Delta_{\text {inst }}$ was found to be constant within an average $1 \sigma$ standard deviation of $\pm 0.2 \%$ over the whole intensity range (Fig. 4). The range of the primary beam intensity during all in situ analyses performed in this study was 10 to $15 \mathrm{nA}$.

\subsubsection{Matrix effect}

As the $\mathrm{Mg}$ content in inorganic calcites and also within the same test and between tests of foraminifera can vary (e.g. Erez, 2003; Eggins et al., 2004), the influence of $\mathrm{Mg}$ content on the IMF has to be tested. The calcite reference materials used in this study have different $\mathrm{MgO}$ contents ( $0 \%$ for ENS $0,0.012 \mathrm{wt} . \%$ for BRET 105E and $0.42 \mathrm{wt} \%$ for MEX). This is completely within the range of $\mathrm{MgO}$ contents for Globorotaliids, which have less than 0.12 wt.\% $\mathrm{MgO}$ (Blackmon and Todd, 1959). For the three calcite reference materials, we obtained the same IMF, within the analytical uncertainty, strongly suggesting that the $\mathrm{Mg}$ content does not affect the IMF at this level. The

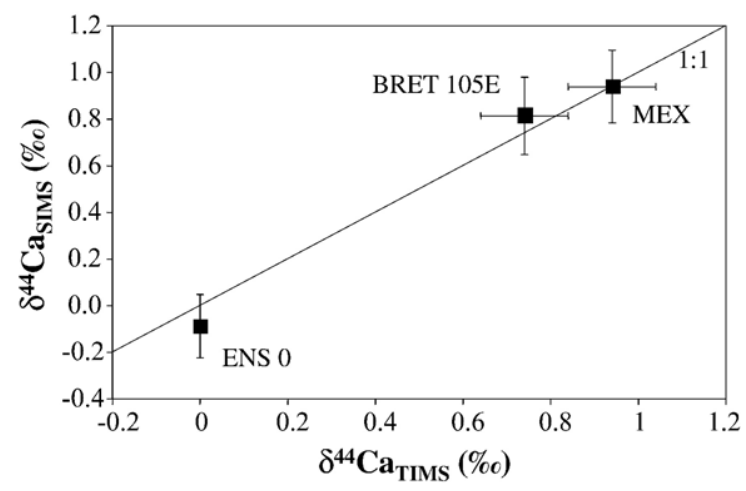

Fig. 6. $\delta^{44} \mathrm{Ca}$ measured by SIMS relative to $\delta^{44} \mathrm{Ca}$ measured by TIMS. Since MEX was used to determine the instrumental fractionation, its value is, by definition, exactly on the $1: 1$ line. Note that the two other reference materials are in good agreement with TIMS data, demonstrating the reliability of the ion microprobe $\delta^{44} \mathrm{Ca}$ analysis. 
a)

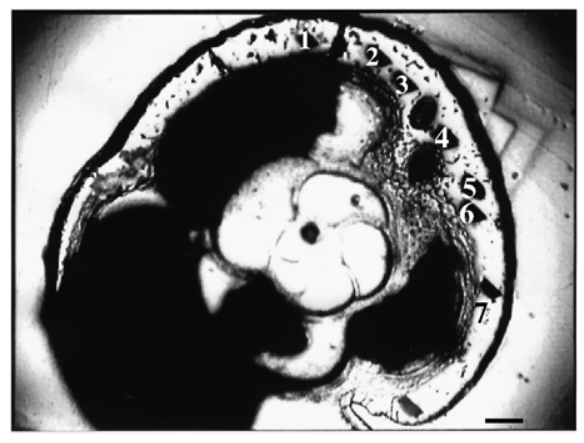

Foraminifera \#1

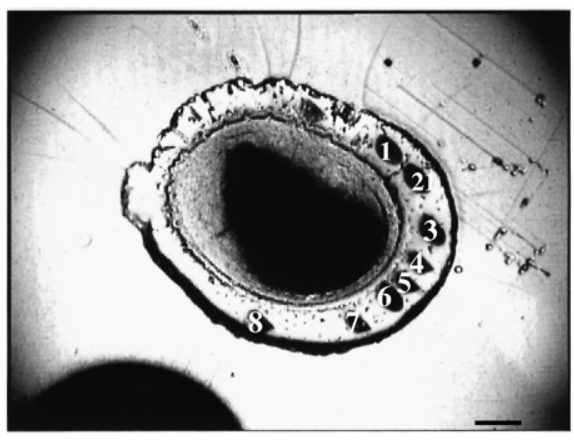

Foraminifera \#2

b)

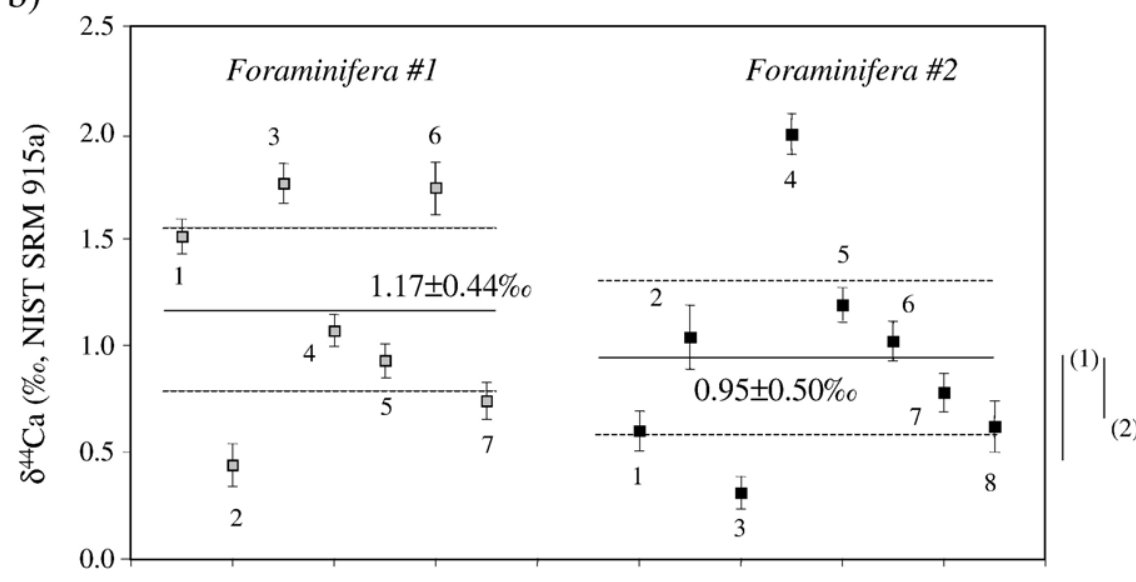

Analysis \#

Fig. 7. a) Pictures of the two specimen of $G$. inflata measured in this study. The position of the analytical points is indicated for each foraminifera. Scale bars are $15 \mu \mathrm{m}$. b) $\delta^{44} \mathrm{Ca}$ intratest variability in the 2.8-Ma old G. inflata tests. Solid lines indicate the mean $\delta^{44} \mathrm{Ca}\left(\bar{\delta}^{44} \mathrm{Ca}\right)$ obtained over the two foraminifera analysis and dashed lines indicate $\bar{\delta}^{44} \mathrm{Ca}+1 \sigma$ and $\bar{\delta}^{44} \mathrm{Ca}-1 \sigma$ values, where $1 \sigma$ is the standard deviation. Despite significant intratest variability, mean $\delta^{44} \mathrm{Ca}$ are similar for both tests, within external error. The ion microprobe $\delta^{44} \mathrm{Ca}$ values are also compared with literature data: (1) Fantle and DePaolo (2005) for bulk carbonates with ages between 2.55 and 3.19 Ma, and (2) Sime et al. (2005) for G. inflata of different box-core locations in North Atlantic and Indian Ocean.

$\mathrm{MgO}$ content in the studied foraminifera was measured by electron microprobe and found to be systematically lower than the detection limit $(\approx 0.05$ wt.\%). Therefore, the same IMF as for reference materials is expected.

\subsubsection{Drift of instrumental mass fractionation with time}

In some sessions, a slight drift in the IMF may be observed with time. This drift rarely exceeded $1 \%$ during a one-day analysis period $(\approx 15 \mathrm{~h})$. To check if there was a drift during the day, we applied the "standard bracketing" technique with measurements of MEX reference material every $\approx 40$ points. If a drift lower than $1 \%$ was observed during one session, we applied a linear regression with time for the IMF drift and we corrected each sample measurement accordingly. If the drift was too significant, the data were discarded.

\section{Results}

\subsection{Reference material analyses}

The point-to-point reproducibility (or external precision) was estimated by repeated analyses of three reference materials under strictly identical analytical conditions. The $\delta^{44} \mathrm{Ca}$ values of the reference materials were constant within a typical $1 \sigma$ standard deviation between \pm 0.13 and $0.25 \%$ (Fig. 5). Consequently, the 
calcium isotope composition of the reference materials can be considered homogeneous at the spatial resolution of the technique and within this uncertainty. The internal precision over the 20 cycles of a single measurement is less than $0.1 \%$.

To check the accuracy of ion probe technique, we used MEX as the reference material and BRET 105E and ENS 0 were considered as unknown samples. We calculated the $\delta^{44} \mathrm{Ca}$ values of BRET and ENS 0 with the instrumental mass fractionation determined by the measurements of MEX. The ion probe value for BRET $105 \mathrm{E}$ was $0.72 \pm 0.16 \%$ o $(1 \sigma)$, which is in excellent agreement with the TIMS value $\left(\delta^{44} \mathrm{Ca}=0.74 \pm 0.11 \%\right.$ ), and the ion probe value for ENS 0 was $-0.09 \pm 0.14 \%$, which is again indistinguishable from the theoretical value of $0 \%$ (Fig. 6).

\subsection{Foraminifera tests}

We applied the in situ $\mathrm{Ca}$ isotopes measurement technique developed on calcite reference materials and described above, on specimen of the planktonic foraminifera, $G$. inflata, dated at $2.8 \mathrm{Ma}$. The aim was to check the variability of $\delta^{44} \mathrm{Ca}$ in natural foraminiferal tests.

We used the intensities of contaminant elements ( $\mathrm{Si}$, $\mathrm{Al})$ to filter the calcium isotope data set and to remove any analyses that could be significantly affected by sample contamination (Allison and Austin, 2003; Vigier et al., 2007).

For this, we performed several in situ $\delta^{44} \mathrm{Ca}$ analyses in two different tests of $G$. inflata. $\delta^{44} \mathrm{Ca}$ values range from 0.44 to $1.96 \pm 0.2 \%$ and 0.31 to $1.99 \pm 0.2 \%$ (Fig. 7 ). The averages obtained for each foraminifera are very close: $1.17 \pm 0.44(1 \sigma) \%$ and $0.95 \pm 0.5(1 \sigma) \%$, respectively. These $\delta^{44} \mathrm{Ca}$ values are also similar to $\delta^{44} \mathrm{Ca}$ measurements of Sime et al. (2005) on G. inflata of different box-core locations in North Atlantic and Indian Ocean $\left(\delta^{44}\right.$ Ca ranging from 0.67 to $0.9 \%$ ), suggesting that seawater $\delta^{44} \mathrm{Ca}$ has not varied significantly since $2.8 \mathrm{Ma}$. Our $\delta^{44} \mathrm{Ca}$ measurements are also similar to calcium isotopic values obtained on bulk carbonates of similar ages (2.55 and 3.19 Ma: $0.87 \pm 0.1 \%$ and $0.67 \pm 0.4 \%$, respectively, Fantle and DePaolo, 2005).

\section{Discussion}

${ }^{44} \mathrm{Ca} / 40 \mathrm{Ca}$ ratios measured by ion microprobe are constant within analytical uncertainty in inorganic calcite reference materials, but are variable in foraminifera tests. This kind of variability has already been observed for boron and oxygen isotopes in corals. The $\delta^{11} \mathrm{~B}$ and $\delta^{18} \mathrm{O}$ variations have been shown to be independent of analytical artefacts and have been related to $\mathrm{pH}$ variations and to kinetic effects during calcite precipitation (Rollion-Bard et al., 2003). The scale of sampling of our study should be able to detect $\delta^{44} \mathrm{Ca}$ heterogeneities, which would not be apparent when analysing the entire foraminiferal test chambers. A significant intratest variability has already been observed by Allison and Austin (2003) using SIMS for $\mathrm{Sr} /$ $\mathrm{Ca}$ and $\mathrm{Mg} / \mathrm{Ca}$ ratios in benthic foraminifera Ammonia batavus and by Eggins et al. (2004) for $\mathrm{Mg} / \mathrm{Ca}$ ratio measured in the planktonic foraminifera Orbulina universa. Allison and Austin (2003) interpreted these variations as the juxtaposition of calcite of different ages as the test is formed. Eggins et al. (2004) suggest that these variations are due to diurnal changes in the biological activity of algal symbionts. Erez (2003) also observed $\mathrm{Mg}$ variation in benthic foraminifera Amphistegina lobifera and linked it to differences in the biomineralization processes of primary and secondary calcites (Bentov and Erez, 2006). Several factors could affect the $\delta^{44} \mathrm{Ca}$ values of the foraminifera chambers i.e. variations in precipitation rates, temperature, possible ontogenic effects or differences between primary and secondary calcite.

A recent study by Lemarchand et al. (2004) of calcium isotopes in synthetic calcites suggests that $\delta^{44} \mathrm{Ca}$ is strongly dependent on the rate of crystal growth. This relationship was also observed in sclerosponges (Ceratoporella nicholsoni and Acanthochaetetes wellsi (Gussone et al., 2005)). The relationship between $\mathrm{Ca}$ isotope fractionation of calcite $\left(\alpha_{\mathrm{cc}}\right)$ and the precipitation rate $R$ is the following:

$$
1000 \times \ln \left(\alpha_{\mathrm{cc}}\right)=-1.91+0.37 \times \log (R)
$$

with $R$ in $\mu \mathrm{mol} \mathrm{m}{ }^{-2} \mathrm{~h}^{-1}$ (Gussone et al., 2005).

Using this formula, our measured $\delta^{44} \mathrm{Ca}$ range would correspond to a $R$ variation of $500000 \mu \mathrm{mol} \mathrm{m} \mathrm{m}^{-2} \mathrm{~h}^{-1}$. In foraminifera, the precipitation rate has been estimated to range between 1-4 $\mu \mathrm{mol} \mathrm{m} \mathrm{m}^{-2} \mathrm{~h}^{-1}$ (Carpenter and Lohman, 1992; Lea et al., 1995) and $\approx 40 \mu \mathrm{mol} \mathrm{m}^{-2} \mathrm{~h}^{-1}$ (Erez, 1983). So, if the whole $\delta^{44} \mathrm{Ca}$ variation measured in the two specimen of $G$. inflata was due to variations in precipitation rate, this would require unrealistic changes in growth rate. Therefore variation in $R$ alone can hardly explain our $\delta^{44}$ Ca range.

For some species (e.g. G. sacculifer), some authors have found that temperature variation can affect the calcium isotope fractionation by up to $0.2 \%$ per ${ }^{\circ} \mathrm{C}$ (Nägler et al., 2000). G. inflata, like all globorotaliids, produce calcite both in surface waters where they live and 
in deeper water where they sink for their reproduction (Hemleben et al., 1989). The $\delta^{44} \mathrm{Ca}$ range measured in each foraminifera would correspond to a temperature variation of 7.6 and $8.4 \pm 0.2{ }^{\circ} \mathrm{C}$, respectively. This temperature variation is compatible with the mode of calcification of $G$. inflata. However, Sime et al. (2005) found no relationship between $\delta^{44} \mathrm{Ca}$ and temperature for this species in a temperature range of $2.4{ }^{\circ} \mathrm{C}$ (from 9.4 to $11.8^{\circ} \mathrm{C}$ ). Without further constraints on the behaviour of $\delta^{44} \mathrm{Ca}$ in $G$. inflata as a function of temperature, it is difficult to attribute $\delta^{44} \mathrm{Ca}$ variations entirely to temperature changes.

Some ontogenic (development stage) effects on proxy incorporation have been identified in benthic (Wefer et al., 1981; Boyle, 1995; Hintz et al., 2006) and in planktonic foraminifera (Bijma et al., 1998). The latter found $\delta^{18} \mathrm{O}$ and $\delta^{13} \mathrm{C}$ variation in planktonic foraminifera Globigerinella siphonifera of up to $0.4 \%$ for oxygen isotopes and $1.5 \%$ for carbon isotopes due to ontogenic effects. However, such changes over the lifespan of individuals are not fully understood yet. Hintz et al. (2006) proposed that this ontogenic effect could be due to biomineralization processes or precipitation of an unstable phase of $\mathrm{Mg}$-rich calcium carbonate. As there are some ontogenic effects on $\delta^{18} \mathrm{O}$ and $\delta^{13} \mathrm{C}$ detected in foraminifera tests, these effects may also change the $\delta^{44} \mathrm{Ca}$ values.

In perforate foraminifera (planktonic and benthic), the test consists of successive laminations of primary and secondary calcite (Erez, 2003). The primary calcite precipitates over newly formed organic matrix. This calcite is enriched in $\mathrm{Mg}, \mathrm{Na}$ and $\mathrm{S}$. The secondary calcite consists of a low-Mg calcite. This calcite is formed from the vacuolization of seawater after a modification within the cytoplasm (decrease of $\mathrm{Mg} / \mathrm{Ca}$ ratio, increase of $\mathrm{pH} . .$. .). It was recently observed that the primary calcite is at least $2 \%$ lower in $\delta^{18} \mathrm{O}$ than the secondary calcite (Rollion-Bard et al., 2006). Even if the exact cause of this depletion in the light isotope is not yet fully understood, it is probably linked to the two different processes of biomineralization involved in the formation of primary and secondary calcite. This difference could also have some effect on the $\delta^{44} \mathrm{Ca}$, although no relationship was found between our $\delta^{44} \mathrm{Ca}$ values and $\mathrm{Mg} / \mathrm{Ca}$ ratios measured in the same spot (not shown here).

The natural variations of $G$. inflata $\delta^{44} \mathrm{Ca}$ cannot be explained by temperature change only and/or by growth variation only. Rather, differences between primary/ secondary calcite and ontogenic effects are inferred. In fact, $\delta^{44} \mathrm{Ca}$ variations are probably the result of the combination of several varying parameters. In order to deconvolve the effect of each parameter on $\delta^{44} \mathrm{Ca}$ internal variations measured by in situ methods, studies of experimentally grown foraminifera are required.

\section{Conclusions}

An ion microprobe technique has been developed for $\delta^{44} \mathrm{Ca}$ measurements in carbonates with a spatial resolution of about $20 \mu \mathrm{m}$. Under suitable vacuum conditions and after 3 min of pre-sputtering, it has been shown that the instrumental fractionation, $\Delta_{\text {inst }}$, was constant with a standard deviation $\approx 0.15 \%$, in spite of variations in analytical conditions including primary ion beam intensity and sputtering time. Under these analytical conditions, stability of $\Delta_{\text {inst }}$ values over the duration of a session can be expected.

We applied this technique to two planktonic foraminifera, $G$. inflata, dated at $2.8 \mathrm{Ma}$. The overall variation of $\delta^{44} \mathrm{Ca}$ measured in a single test is $1.7 \%$, about 10 times the uncertainty of the measurement performed on calcite reference materials. This intratest variation can be explained by several processes such as temperature variation, precipitation rate variation, ontogenic effects or differences between primary and secondary calcite. It is unlikely that only one of these processes is responsible for the total variation, more probably the measured $\delta^{44} \mathrm{Ca}$ range results from a combination of several mechanisms.

Despite this intratest variation, the average $\delta^{44} \mathrm{Ca}$ for each foraminifer test is constant and is in agreement with previous $\delta^{44} \mathrm{Ca}$ data for this age. This strongly suggests that in situ $\delta^{44} \mathrm{Ca}$ measurements in foraminifera test are significant when $\approx 5$ measurements are performed on a single test.

Measurements of $\mathrm{Ca}$ isotopes by ion microprobe on foraminifera grown under controlled conditions are clearly needed in order to better understand the role of the different possible causes of the variations highlighted in this study.

\section{Acknowledgments}

We thank A. Eisenhauer and his team for running $\mathrm{Ca}$ isotopes on our reference materials. We would like to express thanks to M. Chaussidon and J. Carignan (CRPG, France) for fruitful discussion. P. Burnard (CRPG, Nancy) is thanked for his careful reading of the manuscript. D. Mangin and M. Champenois are acknowledged for their technical help for the 1270 ion microprobe measurements. Many thanks to Isabella Premoli Silva for providing samples from the Shatsky Rise. The associate editor, Jeremy Fein, and two anonymous reviewers are 
acknowledged for the improvement of this paper. This is a CRPG-CNRS contribution no. 1877.

\section{References}

Allison, N., Austin, W.E.N., 2003. The potential of ion microprobe analysis in detecting geochemical variations across individual foraminifera tests. Geochem. Geophys. Geosyst. 4. doi:10.1029/ 2002GC000430.

Benninghoven, A., Rüdenauer, F.G., Werner, H.W., 1987. Secondary ion mass spectrometry: basic concepts. Instrumental Aspects, Applications, and Trends. Wiley, New York, p. 1227.

Bentov, S., Erez, J., 2006. Impact of biomineralization processes on the $\mathrm{Mg}$ content of foraminifera shells: a biological perspective. Geochem. Geophys. Geosyst. 7, Q01P08. doi:10.1029/2005GC001015.

Bijma, J., Hemleben, C., Huber, B.T., Erlenkeuser, H., Kroon, D., 1998. Experimental determination of the ontogenic stable isotope variability in two morphotypes of Globigerinella siphonifera (d'Orbigny). Mar. Micropaleontol. 35, 141-160.

Blackmon, P.D., Todd, R., 1959. Mineralogy of some foraminifera as related to their classification and ecology. J. Paleontol. 33, 1-15.

Böhm, F., Gussone, N., Eisenhauer, A., Dullo, W.-C., Reynaud, S., Paytan, A., 2006. Calcium isotope fractionation in modern scleractinian corals. Geochim. Cosmochim. Acta 70, 4452-4462.

Boyle, E.A., 1995. Limits on benthic foraminiferal chemical analyses as precise measures of environmental properties. J. Foraminiferal Res. 25, 4-13.

Carignan, J., Cardinal, D., Eisenhauer, A., Galy, A., Rehkämper, M., Wombacher, F., Vigier, N., 2004. A reflection on $\mathrm{Mg}, \mathrm{Cd}, \mathrm{Ca}, \mathrm{Li}$ and $\mathrm{Si}$ isotopic measurements and related reference materials. Geostand. Geoanal. Res. 28, 139-148.

Carpenter, S.J., Lohman, K.C., 1992. Sr/Mg ratios of modern marine calcite: empirical indicators of ocean chemistry and precipitation rate. Geochim. Cosmochim. Acta 56, 1837-1849.

Clementz, M.T., Holden, P., Koch, P.L., 2003. Are calcium isotopes a reliable monitor of trophic level in marine settings? Int. J. Osteoarchaeol. 13, 29-36.

Coplen, T.B., Böhlke, J.K., De Bièvre, P., Ding, T., Holden, N.E., Hopple, J.A., Krousse, R., Lamberty, A., Peiser, H.S., Revesz, K., Rieder, S.E., Rosmon, K.J.R., Roth, E., Taylor, P.D.P., Vocke, R.D.J., Xiao, Y.K., 2002. Isotope-abundance variations of selected elements (IUPAC technical report). Pure Appl. Chem. 74, 1987-2017.

De Chambost, E., 1997. User's Guide for Multicollector Caméca IMS 1270. Caméca, Courbevoie, France.

De La Rocha, C., DePaolo, D.J., 2000. Isotopic evidence for variations in the marine calcium cycle over the Cenozoic. Science 289, $1176-1178$.

Eggins, S.M., Sadekov, A., De Deckker, J., 2004. Modulation and daily banding of $\mathrm{Mg} / \mathrm{Ca}$ in Orbulina universa test by symbiont photosynthesis and respiration: a complication for seawater thermometry? Earth Planet. Sci. Lett. 225, 411-419.

Eisenhauer, A., Nägler, T., Stille, P., Kramers, J., Gussone, N., Bock, B., Fietzke, J., Hippler, D., Schmitt, A.-D., 2004. Proposal for international agreement on Ca notation as result of the discussions from the workshops on stable isotope measurements in Davos (Goldschmidt 2002) and Nice (EGS-AGU-EUG 2003). Geostand. Geoanal. Res. 28, 149-151.

Erez, J., 1983. Calcification rates, photosynthesis and light in planktonic foraminifera. In: Westbroek, P., de Jong, E. (Eds.),
Biomineralization and Biological Metal Accumulation. D. Reichel editing company, pp. 307-312.

Erez, J., 2003. The source of ions for biomineralization in foraminifera and their implications for paleoceanographic proxies. In: Dove, P., De Yoreo, J., Weiner, S. (Eds.), Reviews in Mineralogy and Geochemistry, Volume 54, Biomineralization. Mineral Society of America Geochemical Society, pp. 115-149.

Fantle, M.S., DePaolo, D.J., 2005. Variations in the marine Ca cycle over the past 20 million years. Earth Planet. Sci. Lett. 235, $102-117$.

Farkas, J., Buhl, D., Blenkinsop, J., Veizer, J., 2007. Evolution of the oceanic calcium cycle during the late Mesozoic: evidence from $\delta^{44 / 40} \mathrm{Ca}$ of marine skeletal carbonates. Earth Planet. Sci. Lett. 253, 96-111.

Fletcher, I.R., McNaughton, N.J., Pigeon, R.T., Rosman, K.J.R., 1997. Sequential closure of $\mathrm{K}-\mathrm{Ca}$ and $\mathrm{Rb}-\mathrm{Sr}$ isotopic systems in Archaean micas. Chem. Geol. 138, 289-301.

Gussone, N., Eisenhauer, A., Tiedemann, R., Haug, G.H., Heuser, A., Bock, B., Nägler, Th.F., Müller, A., 2004. Reconstruction of Caribbean Sea surface temperature and salinity fluctuations in response to the Pliocene closure of the Central American Gateway and radiative forcing, using $\delta^{44 / 40} \mathrm{Ca}, \delta^{18} \mathrm{O}$ and $\mathrm{Mg} / \mathrm{Ca}$ rations. Earth Planet. Sci. Lett. 227, 201-214.

Gussone, N., Böhm, F., Eisenhauer, A., Dietzel, M., Heuser, A., Teichert, B.M.A., Reitner, J., Wörheide, G., Dullo, W.-C., 2005. Calcium isotope fractionation in calcite and aragonite. Geochim. Cosmochim. Acta 69, 4485-4494.

Gussone, N., Langer, G., Thoms, S., Nehrke, G., Eisenhauer, A., Riebesell, U., Wefer, G., 2006. Cellular calcium pathways and isotope fractionation in Emiliania huxleyi. Geology 34, 625-628.

Hemleben, C., Spindler, M., Anderson, O.R., 1989. Modern Planktonic Foraminifera. Springer-Verlag, New York. 363 pp.

Heuser, A., Eisenhauer, A., Böhm, F., Wallmann, K., Gussone, N., Pearson, P.N., Nägler, T.F., Dullo, W.-C., 2005. Calcium isotope $\left(\delta^{44 / 40} \mathrm{Ca}\right)$ variations of Neogene planktonic foraminifera. Paleoceanography 20, PA2013.

Hintz, H.J., Shaw, T.J., Bernhard, J.M., Chandler, G.T., McCorckle, D.C., Blanks, J.K., 2006. Trace/minor element:calcium ratios in cultured benthic foraminifera. Part II: ontogenic variation. Geochim. Cosmochim. Acta 70, 1964-1976.

Hippler, D., Eisenhauer, A., Nägler, T.F., 2006. Tropical Atlantic SST history inferred from Ca isotope thermometry over the last $140 \mathrm{ka}$. Geochim. Cosmochim. Acta 70, 90-100.

Immenhauser, A., Nägler, T.F., Steuber, T., Hippler, D., 2005. A critical assessment of mollusk ${ }^{18} \mathrm{O} /{ }^{16} \mathrm{O}, \mathrm{Mg} / \mathrm{Ca}$, and ${ }^{44} \mathrm{Ca} /{ }^{40} \mathrm{Ca}$ ratios as proxies for Cretaceous seawater temperature seasonality. Palaeogeogr. Palaeoclimatol. Palaeoecol. 215, 221-237.

Janssens, T., Huyghebaert, C., Vandervorst, W., Gildenpfenning, A., Brongersma, H.H., 2003. On the correlation between $\mathrm{Si}^{+}$yields and surface oxygen concentration using in-situ SIMS-LEIS. Appl. Surf. Sci. 203-204, 30-34.

Langer, G., Gussone, N., Nehrke, G., Riebesell, U., Eisenhauer, A., Thoms, S., 2007. Calcium isotope fractionation during coccolith formation in Emiliania huxleyi: independence of growth and calcification rate. Geochem., Geophys., Geosyst. 8, Q05007. doi:10.1029/2006GC001422.

Lea, D.W., Martin, P.A., Chan, D.A., Spero, H.J., 1995. Calcium uptake and calcification rate in the planktonic foraminifera Orbulina universa. J. Foraminiferal Res. 25, 14-23.

Lemarchand, D., Wasserburg, G.J., Papanastassiou, D.A., 2004. Ratecontrolled calcium isotope fractionation in synthetic calcite. Geochim. Cosmochim. Acta 68, 4665-4678. 
Marriott, C.S., Henderson, G.M., Belshaw, N.S., Tudhope, A.W., 2004. Temperature dependence of $\delta^{7} \mathrm{Li}, \delta^{44} \mathrm{C}$ and $\mathrm{Li} / \mathrm{Ca}$ during growth of calcium carbonate. Earth Planet. Sci. Lett. 222, 615-624.

Marshall, B.D., DePaolo, D.J., 1982. Precise age determinations and petrogenic studies using the $\mathrm{K}-\mathrm{Ca}$ method. Geochim. Cosmochim. Acta 53, 917-922.

Martin, P.A., Lea, D., 2002. A simple evaluation of cleaning procedures on fossil benthic foraminiferal $\mathrm{Mg} / \mathrm{Ca}$. Geochem. Geophys. Geosyst. 3. doi:10.1029/2001GC000280.

Nägler, T.F., Villa, I.M., 2000. In pursuit of the ${ }^{40} \mathrm{~K}$ branching ratios: $\mathrm{K}-\mathrm{Ca}$ and ${ }^{39} \mathrm{Ar}-{ }^{40} \mathrm{Ar}$ dating of gem silicates. Chem. Geol. 169, $5-16$.

Nägler, T.F., Eisenhauer, A., Müller, A., Hemleben, C., Kramers, J., 2000. The $\delta^{44} \mathrm{Ca}$-temperature calibration on fossil and cultured Globigerinoides sacculifer: new tool for reconstruction of past sea surface temperature. Geochem. Geophys. Geosyst. 1 2000GC000091.

Pena, L.D., Calvo, E., Cacho, I., Eggins, S., Pelejero, C., 2005. Identification and removal of $\mathrm{Mn}-\mathrm{Mg}$-rich contaminant phases on foraminiferal tests: implications for $\mathrm{Mg} / \mathrm{Ca}$ past temperature reconstructions. Geochem. Geophys. Geosyst. 6, Q09P02. doi:10.1029/2005GC000930.

Rollion-Bard, C., Chaussidon, M., France-Lanord, C., 2003. pH control on oxygen isotopic composition of symbiotic corals. Earth Planet. Sci. Lett. 215, 275-288.

Rollion-Bard, C., Erez, J., Zilberman, T., Segev, E., 2006. Intra-shell oxygen isotope ratios in the benthic foraminiferan Amphistegina lobifera and the influence of seawater carbonate chemistry on this ratio. Geophys. Res. Abstr. 8, EGU06-A-02753.

Sahijpal, S., Goswami, J.N., Davis, A.M., 2000. K, Mg, Ti and Ca isotopic compositions and refractory trace element abundances in hibonites from CM and CV meteorites: implications for early solar system processes. Geochim. Cosmochim. Acta 64, 1989-2005.
Sangely, L., Chaussidon, M., Michels, R., Huault, V., 2005. Microanalysis of carbon isotope composition in organic matter by secondary ion mass spectrometry. Chem. Geol. 223, 179-195.

Schmitt, A.-D., Stille, P., Venneman, T., 2003. Variations of the ${ }^{44} \mathrm{Ca} /{ }^{40} \mathrm{Ca}$ ratio in seawater during the past 24 million years: evidence from $\delta^{44} \mathrm{Ca}$ and $\delta^{18} \mathrm{O}$ values of Miocene phosphates. Geochim. Cosmochim. Acta 67, 2607-2614.

Shimizu, N., Hart, S.R., 1982. Isotope fractionation in secondary ion mass spectrometry. J. Appl. Phys. 53, 1303-1311.

Sime, N.G., De La Rocha, C.L., Galy, A., 2005. Negligible temperature dependence of calcium isotope fractionation in 12 species of planktonic foraminifera. Earth Planet. Sci. Lett. 232, 51-66.

Skulan, J., DePaolo, D.J., 1999. Calcium isotope fractionation between soft and mineralized tissues as a monitor of calcium use in vertebrates. Proc. Nat. Acad. Sci. 96, 13,709-13,713.

Skulan, J.L., DePaolo, D.J., Owens, T.L., 1997. Biological control of calcium isotopic abundances in the global calcium cycle. Geochim. Cosmochim. Acta 61, 2505-2511.

Vigier, N., Rollion-Bard, C., Spezzaferri, S., Brunet, F., 2007. In situ measurements of $\mathrm{Li}$ isotopes in foraminifera. Geochem. Geophys. Geosyst. 7, Q01003. doi:10.1029/2006GC001432.

Weber, D., Zinner, E., Bischoff, A., 1995. Trace element abundances and magnesium, calcium, and titanium isotopic compositions of grossite-containing inclusions from the carbonaceous chondrite Acfer 182. Geochim. Cosmochim. Acta 59, 803-823.

Wefer, G., Killingley, J.S., Lutze, G.F., 1981. Stable isotopes in recent larger foraminifera. Palaeogeogr. Palaeoclimatol. Palaeoecol. 33, 253-270.

Zhu, P., MacDougall, J.D., 1998. Calcium isotopes in the marine environment and the oceanic calcium cycle. Geochim. Cosmochim. Acta 62, 1691-1698. 